\title{
PENGARUH KUALITAS PRODUK DAN BRAND IMAGE TERHADAP MINAT BELI MOTOR MATIK
}

\author{
Didi Zainuddin
}

\author{
Program Studi Teknik Industri, FTIK \\ Universitas Indraprasta PGRI \\ Email : didiza.gadept@gmail.com
}

Diterima: Oktober 2018; Disetujui: Nopember 2018; dipublikasikan: Desember 2018

\begin{abstract}
ABSTRAK
Penelitian ini bertujuan untuk mengetahui seberapa besar keinginan konsumen terhadap minat beli motor matik sehingga perlu dilakukan pengujian berdasarkan beberapa variabel yaitu variabel kualitas produk dan brand image, adapun penelitian ini menggunakan metode kualitatif dimana data yang didapat melalui pertanyaan yang disebarkan kepada masyarakat pengguna sepeda motor sebanyak 65 responden. Adapun hasil penelitian yang didapat menunjukan bahwa adanya pengaruh antara kualitas produk, Brand Image kepada minat beli minat secara simultan yaitu $82.5 \%$ sedangkan selisihnya $17.5 \%$ yaitu menggambarkan adanya variabel lain yang menyebabkan minat beli konsumen terhadap motor matik. Dan berdasarkan hasil pengujian secara parsial hanya brand image saja yang memiliki hubungan langsung kepada minat beli secara parsial sebesar 23\% sedangkan kualitas produk tidak berpengaruh signifikan kepada minat beli konsumen.
\end{abstract}

Kata kunci : Kualitas Produk, Brand Image, Minat Beli

\begin{abstract}
This research is aimed to find out how much consumers want to buy an automatic motorbike so that it needs to be tested based on several variables, namely product quality variables and brand image, while this research uses qualitative methods where the data obtained through questions distributed to motorcycle users as much as 65 respondent. The results obtained show that there is an influence between product quality, Brand Image to interest in buying simultaneously, which is $82.5 \%$ while the difference is $17.5 \%$, which illustrates the existence of other variables that cause consumer buying interest in automatic motors. And based on the results of partial testing only brand image has a direct relationship to buying interest partially by $23 \%$ while product quality does not significantly influence consumer buying interest.
\end{abstract}

Keywords: Product Quality, Brand Image, Interest to Buy 
Volume 10, No. 3, Desember 2018, pp.220-227

e-ISSN: 2502-5449

p-ISSN: 2085-2266

http://journal.lppmunindra.ac.id/index.php/sosio_ekons

DOI: http://dx.doi.org/10.30998/sosioekons.v10i3.2902

\section{PENDAHULUAN}

Dengan tingginya mobilisasi masyarakat serta adanya kemacetan lalu lintas yang menjadi pemandangan sehari-hari, banyak masyarakat beralih ke mode transportasi yang lebih simpel, cepat dan murah untuk menunjang aktivitasnya, dan ketika hidup masyarakat menjadi semakin rumit, terburu-buru oleh waktu maka, masyarakat dituntut untuk mampu mengambil keputusan yang cepat tetapi memiliki resiko yang paling kecil terhadap aktifitas mereka.

maka dari itu masyarakat membutuhkan alternatif kendaraan yang dapat menunjang aktivitasnya. Hal ini merupakan peluang bagi perkembangan industri otomotif kendaraan bermotor roda dua di Indonesia menjadi lebih cepat dan meningkat setiap tahunnya, hal ini seiring dengan kebutuhan dan permintaan masyarakat akan sarana transportasi yang dapat mempermudah aktivitasnya.

Jika dilihat pertumbuhan, perkembangan, dan permintaan sepeda motor di dalam negeri selama beberapa tahun terakhir ini terlihat sangat tinggi dan cendrung meningkat. Dimana perusahaan otomotif berlomba - lomba dalam menciptakan berbagai macam produk sepeda motor yang menarik agar produknya bisa diingat oleh konsumen melalu citra merek sehingga konsumen mau membeli produknya, Kotler dan Armstrong (2013:233) mengemukakan arti tentang citra merek The set of belief held about a particular brand is known as brand image. artinya yaitu sekumpulan keyakinan terhadap suatu merek disebut citra merek. Begitu juga Kotler dan Keller (2012:768) mendefinisikan tentang brand image "Perception and beliefs held by consumers. As reflected in the associations held in consumers memory". sebagai sekumpulan persepsi dan kepercayaan yang dimiliki pelanggan terhadap suatu brand yang direfleksikan melalui asosiasi-asosiasi yang ada dalam memori dan pikiran pelanggan.

Namun demikian, persaingan pasar motor matik terlihat semakin ketat dalam bersaing. Beberapa perusahaan besar terlihat terus berusaha untuk memperbesar pangsa pasarnya agar bisa menarik minat konsumen untuk membeli produknya dengan cara menciptakan jenis kendaraan yang bervariatif seperti motor bebek, matik, dan moge (Motor Gede), serta meningkatkan teknologinya sehingga masyarakat tidak monoton dalam memilih kendaraannya dan hasratnya dapat terpenuhi.

Sehingga Pihak Agen Tunggal Pemegang Merek (ATPM) seperti Honda, Yamaha, Suzuki, Kawasaki, dan TVS berlomba untuk menciptakan produk kendaraan sepeda motor yang berkualitas agar untuk memenuhi kebutuhan masyarakat. Fandy Tjiptono (2008) menyatakan Kualitas produk merupakan suatu penilaian konsumen terhadap keunggulan atau keistimewaan suatu produk.

Hal ini dibuktikan oleh data yang telah dikeluarkan oleh Asosiasi Industri Sepeda Motor Indonesia (AISI) dari berbagai merek pada tahun 2017 sebagai berikut :

Tabel 1.1

Data penjualan Sepeda Motor 2013 s/d 2017

\begin{tabular}{ccccccc}
\hline Periode & Honda & Yamaha & Suzuki & Kawasaki & TVS & Total \\
\hline 2013 & 4.696 .999 & 2.492 .596 & 393.803 & 151.703 & 8.778 & 7.743 .879 \\
2014 & 5.051 .100 & 2.371 .082 & 275.067 & 165.371 & 9.575 & 7.867 .195 \\
2015 & 4.453 .888 & $1,798,630$ & 109.882 & 115.008 & 2.747 & 6.480 .155 \\
2016 & 4.380 .888 & $1,394,078$ & 56.824 & 97.622 & 1.873 & 5.931 .285 \\
2017 & 4.385 .888 & $1,348,211$ & 72.191 & 78.637 & 1.176 & 5.886 .103 \\
\hline Total & 22.968 .763 & 4.863 .678 & 907.767 & 608.341 & 24.149 & 33.908 .617 \\
\hline
\end{tabular}

Sumber: Asosiasi Industri Sepeda Motor Indonesia 


\section{sosio e-kons}

Volume 10, No. 3, Desember 2018, pp.220-227

e-ISSN: $2502-5449$

p-ISSN: 2085-2266

http://journal.lppmunindra.ac.id/index.php/sosio_ekons

DOI: http://dx.doi.org/10.30998/sosioekons.v10i3.2902

Berdasarkan data diatas menggambarkan walaupun tren penjualan kendaraan bermotor terus mengalami penurunan, ada hal menarik yang sangat menonjol dalam perubahan konsumen didalam pemilihan kendaraan bermotor, yaitu jika dianalisis secara cermat akhir - akhir ini masyarakat yang tadinya lebih menyukai motor jenis bebek kini telah terjadi perubahan yang sangat signifikan ke scutic (scuter matic) atau sering disebut motor matik.

Alasannya masyarakat lebih menyukai menggunakan motor metik karena memang lebih praktis bagi konsumen dan lebih ekonomis dari sisi bahan bakar, serta memadukan antara kelincahan, kenyamanan yang dimiliki motor bebek dengan lebih simpelnya mengendarai motor metik dalam hal melewati kemacetan serta bermanuver tanpa harus berganti - ganti persneling, disisi lain dalam pemilihan motor, konsumen sangat memperhatikan merek, kualitas, bentuk tampilan dan teknologi motor tersebut, hal ini sesuai dengan dimensi kualitas produk dalam Fandy Tjiptono (2008) sebagai berikut :

(1) Performance (kinerja), merupakan karakteristik fungsi dan kinerja dari produk inti (core product) yang dibeli atau ditawarkan. Misalnya kemudahan, kecepatan, dan kenyamanan dalam penggunaan produk.

(2) Durability (daya tahan), yang berarti daya tahan usia produk dalam pemakaian, yaitu jumlah pemakaian produk sebelum produk itu digantikan atau rusak. Semakin lama daya tahan produk tersebut dipakai semakin awet, produk yang awet akan dipersepsikan lebih memiliki kualitas yang baik dibanding produk yang cepat habis atau cepat diganti.

(3) Conformance to specifications (kesesuaian dengan spesifikasi), yaitu sejauh mana karakteristik desain dan produk yang memenuhi standar yang telah ditetapkan sebelumnya. Misalnya pengawasan kualitas dan desain, Standar karakteristik operasional suatu produk adalah kesesuaian kinerja produk dengan standar yang telah dinyatakan suatu perusahaan yang telah menciptakan produk tersebut. Hal ini merupakan janji yang harus dipenuhi oleh pencipta produk. Produk yang memiliki kualitas dari dimensi ini berarti sesuai dengan standarnya.

(4) Features (fitur), merupakan karakteristik, ciri-ciri, tambahan asesoris yang melengkapi manfaat dasar suatu produk. Fitur bersifat pilihan atau option bagi konsumen. Fitur ini bisa meningkatkan kualitas produk jika kompetitornya tidak memiliki fitur tersebut,

(5) Reliability (reabilitas) yaitu kemungkinan produk tersebut akan mengalami kerusakan atau gagal pakai (produk gagal). Misalnya pengawasan kualitas produk dan desain, standar karakteristik operasional kesesuaian dengan spesifikasi yang telah ditentukan.

(6) Aesthetics (estetika) yaitu daya tarik produk terhadap panca indera, misalkan bentuk tampilan, model atau desain yang artistik, menarik, warna yang trendi dan sebagainya,

(7) Perceived quality (kesan kualitas) yaitu persepsi konsumen terhadap keseluruhan kualitas atau keunggulan suatu produk. Biasanya karena minimnya pengetahuan pembeli akan atribut atau ciri-ciri produk yang akan dibeli, maka pembeli mempersepsikan kualitasnya dari harga, nama merek, iklan, reputasi perusahaan, maupun pembuatnya,

(8) Serviceability, yaitu kualitas produk yang telah ditentukan atas dasar kemampuan jika diperbaiki: mudah, dan cepat. Produk yang mampu diperbaiki tentu kualitasnya akan lebih tinggi dibandingkan dengan produk yang tidak atau sulit diperbaiki.

Suyadi Prawirosentono, (2002, hal. 2-3) mengatakan menciptakan produk berkualitas terbaik memang akan lebih disukai bagi konsumen bahkan akhirnya dapat meningkatkan volume penjualan. Tetapi lebih dari itu produk berkualitas mempunyai aspek penting lain, yaitu :

a. Konsumen yang membeli produk berdasarkan kualitas, umumnya mempunyai loyalitas produk yang baik dibandingkan dengan konsumen yang membeli berdasarkan harga. Konsumen yang membeli karena kualitas produk akan selalu membeli produk tersebut sampai saat produk tersebut membuatnya merasa tidak puas karena adanya produk lain yang menawarkan lebih berkualitas. Tetapi selama produk tersebut masih melakukan inovasi dan 
perbaikan mutu (Quality Improvement) konsumen akan tetap setia dan akan tetap membelinya. Berbeda dengan konsumen membeli karena harga, mereka akan mencari produk yang harganya lebih murah, apapun mereknya.

b. Bersifat kontradiktif dengan cara pikir bisnis tradisional, ternyata bahwa memproduksi barang berkualitas, tidak secara otomatis akan lebih mahal dengan memproduksi produk berkualitas rendah. Banyak perusahaan merasakan bahwa memproduksi produk bermutu tidak harus berharga mahal tapi kompetitif. Menghasilkan produk berkualitas tinggi secara simultan meningkatkan produktivitas, dengan cara mengefisiensikan penggunaan bahan (reduce materials usage) dan mengurangi biaya yang tidak penting.

c. Menjual barang tidak berkualitas, bisa berakibat akan banyak menerima keluhan dan pengembalian barang yang telah dibeli konsumen. Sehingga biaya perbaikannya menjadi lebih mahal, dan mengakibatkan citra yang buruk bagi perusahaan. berdasarkan ketiga alasan diatas, menciptakan produk berkualitas tinggi akan lebih banyak memberikan profit yang lebih baik bagi produsen, bila dibandingkan dengan menciptakan produk bermutu rendah.

Hal ini dibuktikan dengan data tingkat penjualan kendaraan sepeda motor terlaris sebagai berikut :

Tabel 1.2

Data penjualan Sepeda Motor terlaris 2017

\begin{tabular}{cccc}
\hline No & Merek & Type & Jumlah \\
\hline 1 & Honda & BeAT eSP & 1.624 .479 unit \\
2 & Honda & Scoopy eSP & 570.748 unit \\
3 & Honda & Vario 125 eSP & 570.699 unit \\
4 & Honda & Vario 150 eSP & 439.605 unit \\
5 & Yamaha & Mio M3 125 CW & 262.900 unit \\
\hline
\end{tabular}

Sumber: Asosiasi Industri Sepeda Motor Indonesia

Tabel 1.3

Data penjualan Sepeda Motor terlaris (Jan - Juni) 2018

\begin{tabular}{clll}
\hline No & Merek & \multicolumn{1}{c}{ Type } & \multicolumn{1}{c}{ Jumlah } \\
\hline 1 & Honda & BeAT eSP & 926.744 unit \\
2 & Honda & Scoopy eSP & 387.464 unit \\
3 & Honda & Vario 125 eSP & 309.012 unit \\
4 & Yamaha & Nmax & 261.542 unit \\
5 & Honda & Vario 150 eSP & 238.786 unit \\
\hline
\end{tabular}

Sumber: Asosiasi Industri Sepeda Motor Indonesia

Dari data diatas menggambarkan selain kualitas produk yang diminati konsumen ada hal lain yang menjadi pertimbangan konsumen dalam melakukan pembelian sepeda motor yaitu Brand Image dimana hal itu sangat melekat kuat dalam hati masyarakat dalam menentukan pilihan. "Brand image can be defined as a perception about brand as reflected by the brand association held in consumer memory". Pendapat ini menyatakan bahwa citra merek adalah persepsi tentang merek yang digambarkan oleh asosiasi merek yang ada dalam ingatan dan pikiran konsumen (Keller, 1998:93). 


\section{sosio e-kons}

Volume 10, No. 3, Desember 2018, pp.220-227

e-ISSN: $2502-5449$

p-ISSN: 2085-2266

http://journal.lppmunindra.ac.id/index.php/sosio_ekons

DOI: http://dx.doi.org/10.30998/sosioekons.v10i3.2902

\section{METODE}

Dalam pembahasan penelitian ini metode yang digunakan yaitu dengan pendekatan kualitatif dimana data yang didapat melalui penyebaran angket kepada masyarakat pengguna sepeda motor sebanyak 65 responden. Adapun untuk mengukur hasil jawaban kuesioner menggunakan skala likert dengan regresi berganda. Adapun hasilnya berupa angka, sehingga memudahkan dalam menganalisa dan penafsiran dengan menggunakan perhitungan stastistik.

\section{HASIL DAN PEMBAHASAN}

Dalam menciptakan produk, suatu perusahaan tidak hanya berfikir bagaimana menciptakan produk yang berkualitas saja, tapi perusahaan harus berfikir juga bagaimana produk tersebut bisa diketahui oleh konsumen sehingga ketika produsen ingin menciptakan produk baru, konsumen dapat mengenal siapa yang memproduksi barang tersebut. Harapannya citra merek (Brand Image) yang tertanam di benak dan dipikiran pelanggan dapat menarik minat beli konsumen. Karena merek merupakan salah satu yang dilihat pertama kali oleh pelanggan sebelum melakukan pembelian produk. Menurut Kotler dan Keller (2012:248) "Brand Imagery describes the extrinsic properties of the product or service, including the ways in which the brand attempts to meet customers psychological or social needs". Brand Image menggambarkan sifat ekstrinsik dari suatu produk atau jasa termasuk cara dimana merek berusaha memenuhi kebutuhan psikologis atau sosial pelanggan. Menurut pendapat Keller (2013:97) dimensi-dimensi dalam mendiptakan citra sebuah merek berikut ini:

1. Brand Identity (identitas Merek)

Brand identity merupakan identitas fisik yang berkaitan dengan merek atau produk tersebut sehingga konsumen mudah mengenali dan membedakannya dengan merek atau produk lain, seperti logo, warna, kemasan, lokasi, identitas perusahaan, slogan, dan lain-lain.

2. Brand Personality (Personalitas Merek).

Brand personality yaitu karakter khas suatu merek yang membentuk kepribadian pelanggan, sehingga pelanggan bisa dengan mudah membedakannya dengan merek lain dalam ukuran yang sama, misalnya karakter tegas, kaku, berwibawa, dinamis, kreatif, independen, dan sebagainya.

3. Brand Association (Asosiasi Merek).

Brand Association adalah hal-hal spesifik yang selalu dikaitkan dengan suatu merek, bisa muncul dari penawaran unik suatu produk, aktivitas yang berulang dan berkelanjutan seperti halnya sponsorship, social resposibility, dan isu-isu berkaitan dengan merek, person, simbolsimbol dan makna tertentu yang sangat kuat pada merek itu.

4. Brand Attitude and Behavior (sikap dan perilaku merek).

Brand attitude and behavior adalah perilaku komunikasi dan interaksi merek dengan pelanggan dalam menawarkan keuntungan dan nilai yang dimilikinya. Attitude and behavior menggambarkan sikap dan perilaku pelanggan, aktivitas dan atribut yang melekat pada merek saat berhubungan dengan pelanggan, termasuk perilaku karyawan dan pemilik merek.

5. Brand Benefit and Competence (Manfaat dan Keunggulan Merek).

Brand benefit and competence merupakan nilai-nilai dan keunggulan yang ditawarkan oleh suatu merek kepada pelanggan yang membuat pelanggan dapat merasakan manfaat karena kebutuhan, keinginan, mimpi, dan obsesinya terwujudkan oleh apa yang ditawarkan merek tersebut. 
Volume 10, No. 3, Desember 2018, pp.220-227

e-ISSN: 2502-5449

p-ISSN: 2085-2266

http://journal.lppmunindra.ac.id/index.php/sosio_ekons

Dan berdasarkan hasil penelitian menggambarkan bahwa sebanyak 45 dari 65 responden berjenis kelamin Pria, $65 \%$ dari responden berusia 25 s/d 30 tahun, dan 58,3\% responden berprofesi sebagai mahasiswa/mahasiswi. Adapun dari variabel Kualitas produk dan Brand Image terhadap minat beli menggambarkan tabel yang menunjukan sebagai berikut :

Tabel 1.4

Data Kuesioner Kualitas Produk

\begin{tabular}{|c|c|c|c|c|c|c|c|c|}
\hline No & Variabel & Indikator & STS & TS & $\mathbf{R}$ & $\mathbf{S}$ & SS & Total \\
\hline 1 & & Fungsi Utama Produk & & & & & & \\
\hline 2 & & Pilihan Produk & & & & & & \\
\hline 3 & & Pengembangan Produk & & & & & & \\
\hline 4 & Kualitas Produk & Tingkat Kesesuaian & 11 & 52 & 149 & 206 & 37 & 455 \\
\hline 5 & & Daya Tahan Produk & & & & & & \\
\hline 6 & & Kemudahan Perbaikan & & & & & & \\
\hline 7 & & Penampilan & & & & & & \\
\hline \multicolumn{3}{|c|}{ Persentase } & $2 \%$ & $11 \%$ & $33 \%$ & $45 \%$ & $8 \%$ & $100 \%$ \\
\hline
\end{tabular}

Sumber : Data Primer di olah

Berdasarkan tabel diatas menunjukan bahwa $45 \%$ dari 65 Responden setuju bahwa kualitas produk dapat mempengaruhi minat beli walaupun ada responden yang menyatakan sangat tidak setuju kepada kualitas produk sebesar 2\%. adapun dari tabel Brand Image menggambarkan sebagai berikut :

\section{Tabel 1.5}

Data Kuesioner Brand Image

\begin{tabular}{|c|c|c|c|c|c|c|c|c|}
\hline No & Variabel & Indikator & STS & TS & $\mathbf{R}$ & $\mathbf{S}$ & SS & Total \\
\hline 1 & \multirow{8}{*}{$\begin{array}{l}\text { Brand } \\
\text { Image }\end{array}$} & Merek Menembus budaya \& pasar & \multirow{7}{*}{6} & \multirow{7}{*}{22} & \multirow{7}{*}{126} & \multirow{7}{*}{244} & \multirow{7}{*}{57} & \multirow{7}{*}{455} \\
\hline 2 & & Merek Merubah Prilaku Konsumen & & & & & & \\
\hline 3 & & Merek permudah mengambil tindakan & & & & & & \\
\hline 4 & & Keuntungan dari produk bermerek & & & & & & \\
\hline 5 & & Keuntungan dari Asosiasi Merek & & & & & & \\
\hline 6 & & Kekuatan dari Asosiasi Merek & & & & & & \\
\hline 7 & & Keunikan dari Asosiasi Merek & & & & & & \\
\hline & & Persentase & $1 \%$ & $5 \%$ & $28 \%$ & $54 \%$ & $13 \%$ & $100 \%$ \\
\hline
\end{tabular}

Sumber : Data Primer di olah

Untuk mengetahui pengaruh Kualitas Produk dan Brand Image secara bersama-sama terhadap minat beli dapat diketahui nilai $\mathrm{R}$ square sebagai berikut.

\begin{tabular}{ccccc}
\hline \multicolumn{5}{c}{ Model Summary } \\
Model & $\mathrm{R}$ & R Square & $\begin{array}{c}\text { Adjusted R } \\
\text { Square }\end{array}$ & $\begin{array}{c}\text { Std. Error of } \\
\text { the Estimate }\end{array}$ \\
\hline 1 & $.910^{\mathrm{a}}$ & .825 & .818 & 1.926 \\
\hline Sumber : Data Primer output spss & &
\end{tabular}

Berdasarkan tabel summary diatas $\mathrm{R}$ square menunjukan angka 0.825 angka tersebut menjelaskan pengaruh antara kualitas produk, Brand Image terhadap minat beli dengan koefisien determinasi (KD) sebesar 82.5\% . artinya tingkat pengaruh yang dimiliki kualitas 


\section{sosio e-kons}

Volume 10, No. 3, Desember 2018, pp.220-227

e-ISSN: $2502-5449$

p-ISSN: 2085-2266

http://journal.lppmunindra.ac.id/index.php/sosio_ekons

DOI: http://dx.doi.org/10.30998/sosioekons.v10i3.2902

produk, brand image terhadap minat beli secara simultan yaitu $82.5 \%$ sedangkan selisihnya $17.5 \%$ yaitu menggambarkan adanya variabel lain yang menyebabkan minat beli konsumen terhadap motor matik. Adapun $\mathrm{F}$ penelitian didapat 93.480 dan $\mathrm{F}$ tabel 2.46 sehingga disimpulkan bahwa F Penelitian $93.480>$ F Tabel 2.46 dinyatakan diterima, dimana adanya hubungan linier antara kualitas produk, brand image kepada minat beli. Selanjutnya dalam penelitian ini menguji apakah ada hubungan linier antara kualitas produk terhadap minat beli, dan brand image terhadap minat beli secara parsial.

Untuk melihat hubungan kualitas produk terhadap minat beli yaitu diperoleh angka $\mathrm{t}$ penelitiannya sebesar 1,219 sedangkan $t$ tabelnya 2,00. Berdasarkan angka tersebut dinyatakan jika angka $t$ penelitian $1,219<2,00$ dari angka t tabel artinya tidak ada hubungan yang linier antara kualitas produk terhadap minat beli. selanjutnya apakah ada hubungan linier antara brand image terhadap minat beli secara parsial.

Angka $t$ penelitian dan $t$ tabel yang didapat antara brand image terhadap minat beli yaitu 2,298 untuk t penelitian dan 2,00 untuk t tabel. Berdasarkan hasil diatas jika t penelitian 2,298 > $2.00 \mathrm{t}$ tabel maka artinya adanya hubungan linier antara brand image terhadap minat beli sebesar 0,230 atau 23\%. Dimana citra merek adalah produk atau jasa yang bentuknya menggambarkan merek tersebut dengan beberapa cara dari produk atau jasa lainnya yang dibuat untuk memuaskan kebutuhan yang diinginkan konsumen. Perbedaan ini bersifat fungsional, rasional, dan nyata yang berhubungan dengan kinerja produk dari merek. Perbedaan ini bisa bersifat sebagai simbol, emosional, atau tidak nyata, berhubungan dengan apa yang di representasikan atau digambarkan oleh merek.

Lalu konsumen dapat mengevaluasi produk yang sama secara berbeda tergantung oleh siapa merek produk tersebut dikeluarkan. Mereka belajar mengenai produk tersebut berdasarkan pengalaman dimasa lalu dengan produk tersebut dan bagaimana program pemasarannya, menemukan merek mana yang dapat memenuhi kebutuhan mereka dan mana yang tidak.

\section{SIMPULAN}

Berdasarkan hasil analisis dan pembahasan diatas dapat diambil simpulan yaitu berdasarkan hasil pengujian menggambarkan terdapat pengaruh antara kualitas produk, Brand Image terhadap minat beli sebesar $82.5 \%$. artinya tingkat pengaruh yang dimiliki kualitas produk, brand image terhadap minat beli secara simultan yaitu $82.5 \%$ sedangkan selisihnya $17.5 \%$ yaitu menggambarkan adanya variabel lain yang menyebabkan minat beli konsumen terhadap motor matik.

Dan berdasarkan pengujian secara parsial hanya brand image yang memiliki hubungan langsung terhadap minat beli secara parsial sebesar 23\% sedangkan kualitas produk tidak berpengaruh signifikan secara parsial terhadap minat beli.

\section{SARAN}

Berdasarkan hasil penelitian diatas, saran untuk peneliti selanjutnya agar memperbaiki kekurangan penelitian ini sebagai berikut :

1. Peneliti selanjutnya sebaiknya mencari informasi dan alasan (Variabel) lain yang sedang berkembang sehingga konsumen tertarik untuk membeli motor matik

2. Meningkatkan jumlah dan keberagaman responden, sehingga penelitian selanjutnya memiliki tingkat validitas dan akurasinya lebih baik. 


\section{sosio e-kons}

Volume 10, No. 3, Desember 2018, pp.220-227

e-ISSN: $2502-5449$

p-ISSN: 2085-2266

http://journal.lppmunindra.ac.id/index.php/sosio_ekons

\section{DAFTAR RUJUKAN}

Kotler, P \& Amstrong.G. (2012). Prinsip-prinsip Pemasaran, Edisi 13 Jilid 1. Jakarta: Erlangga Kotler, P \& Keller, K.L. (2012). Marketing Managemen 13, New Jersey : Pearson Prantice Hall, Inc

Keller, K.L. (2013). Strategic Brand Management ; Building, Measuring, and Managing Brand Equity. Fourth Edition Harlow, English : Pearson Education Inc.

Keller, K.L. (1998). Strategic Brand Management : Building, Measuring, and Managing Brand Equity, Prentice Hall: New Jersey.

Prawirosentono, S. (2002). Filosofi Baru Tentang Manajemen Mutu Terpadu Total Quality Management Abad 21 Studi Kasus dan Analisis. Jakarta : Bumi Aksara

Tjiptono, F. (2008). Pemasaran jasa Edisi ketiga, Malang : Bayu Media Publishing.

https://www.cnnindonesia.com/teknologi/20180709180358-384-312775/penjualan-sepedamotor- sepanjang-semester-i-2018

http://www.aisi.or.id/statistic 


\section{sosio e-kons}

Volume 10, No. 2, Agustus 2018, pp. 96-108

e-ISSN: 2502-5449

p-ISSN: 2085-2266

http://journal.lppmunindra.ac.id/index.php/sosio_ekons 